\title{
Feeding associations between capybaras Hydrochoerus hydrochaeris (Linnaeus) (Mammalia, Hydrochaeridae) and birds in the Lami Biological Reserve, Porto Alegre, Rio Grande do Sul, Brazil
}

\author{
Ana C. Tomazzoni ${ }^{1,2}$, Ezequiel Pedó ${ }^{2,3} \&$ Sandra M. Hartz ${ }^{2,4}$ \\ 1 Rua José Gomes Domingues 457, ap. 401, Bairro Santa Fé, 79021-230 Campo Grande, Mato Grosso do Sul, Brasil. \\ E-mail: actomazzoni@yahoo.com.br \\ 2 Programa de Pós-Graduação em Ecologia, Universidade Federal do Rio Grande do Sul. Avenida Bento Gonçalves 9500, \\ Prédio 43422, Caixa Postal 15007, 91501-970 Porto Alegre, Rio Grande do Sul, Brasil. \\ 3 E-mail: ezequiel.pedo@gmail.com \\ ${ }^{4}$ E-mail: hartzsm@ecologia.ufrgs.br
}

\begin{abstract}
Feeding associations between capybaras Hydrochoerus hydrochaeris (Linnaeus, 1766) and some bird species were registered in the Lami Biological Reserve, southern Brazil, through observations in a set of transects established in the five major vegetation types of the study area: shrubby and herbaceous swamps, wet grasslands, sandy grasslands and forests. Data included: date and time, vegetation type, bird species, number of individuals (birds and capybaras), type of prey consumed, foraging strategy of the birds and the behavior of the capybaras in relation to the presence of birds. Five species of birds were registered: Caracara plancus (Miller, 1777), Furnarius rufus (Gmelin, 1788), Machetornis rixosus (Vieillot, 1819), Milvago chimachima (Vieillot, 1816) and Molothrus bonariensis (Gmelin, 1789). The interactions were observed in the shrubby swamp (M. bonariensis), forest (C. plancus) and wet grassland ( $F$. rufus, M. rixosus, M. chimachima). The foraging strategies were: (1) use of the capybara as a perch, hunting from its back (M. rixosus, M. bonariensis); (2) use of the capybara as a beater, hunting in the ground ( $F$. rufus, M. rixosus, M. bonariensis); (3) foraging in the skin of the capybara, by picking the ectoparasites (C. plancus, F. rufus, M. chimachima). Strategies (1) and (2) were employed to catch arthropods flushed from the vegetation. Sometimes, capybaras lay down and exposed the abdomen and lateral areas of their bodies to facilitate cleaning by $M$. chimachima, but the presence of other bird species seemed to be neutral to capybaras.

KEY WORDS. Bird-mammal interaction, feeding behavior, foraging.
\end{abstract}

RESUMO. Associações alimentares entre capivaras (Hydrochoerus hydrochaeris) (Linnaeus) (Mammalia, Hydrochaeridae) e aves na Reserva Biológica do Lami, Porto Alegre, Rio Grande do Sul, Brasil. Foram registradas associações alimentares entre capivaras Hydrochoerus hydrochaeris (Linnaeus, 1766) e aves na Reserva Biológica do Lami, sul do Brasil, por meio de observações em um conjunto de transecções estabelecidas nos cinco principais tipos de vegetação existentes na área: banhado arbustivo, banhado herbáceo, campo úmido, campo arenoso e mata. As informações coletadas foram: data, horário, tipo de vegetação, espécie de ave, número de indivíduos (para aves e capivaras), tipo de presa consumida e estratégia de forrageamento das aves e comportamento das capivaras em relação à presença das aves. Cinco espécies de aves foram registradas: Caracara plancus (Miller, 1777), Furnarius rufus (Gmelin, 1788), Machetornis rixosus (Vieillot, 1819), Milvago chimachima (Vieillot, 1816) and Molothrus bonariensis (Gmelin, 1789). As interações foram observadas no banhado arbustivo (M. bonariensis), na mata (C. plancus) e no campo úmido ( $F$. rufus, M. rixosus, M. chimachima). As estratégias de forrageamento registradas foram: (1) uso da capivara como "poleiro"; (2) uso da capivara como "batedor"; (3) forrageio no pêlo da capivara, para captura de ectoparasitas. As estratégias (1) e (2) foram empregadas pelas aves para capturar artrópodos que saltavam da vegetação pela movimentação das capivaras. Foi observado que as capivaras, em algumas ocasiões, apresentavam comportamento de exposição do abdômen e partes laterais do corpo para facilitar a retirada de ectoparasitas por M. chimachima. A presença das demais espécies de aves não interferiu no comportamento das capivaras.

PALAVRAS CHAVE. Comportamento alimentar, forrageio, interação ave-mamífero. 
Several feeding associations between birds and mammals have been recorded in the literature. In almost all cases, birds are benefited by food acquisition, whereas mammals can be benefited due to cleaning (ectoparasites removal) or food consumption (Rodrigues \& Monteiro-Filho 1996), can be not affected by the association, or can be damaged (when birds eat the flesh taken from wounds in their skin). These interactions are classified as protocooperation, comensalism and semi-parasitism, respectively (ODUM 1988, RugGIERo 1996).

In the terrestrial environment, bird-mammal associations are relatively common and have been reported in several regions of the world. Associations between birds and cattle (Bos taurus Linnaeus, 1758) (Bovidae) and other domestic grazing mammals seem to be widespread (RAND 1953, Heatwole 1965, Smith 1971, Isenhart \& DeSante 1985, Källander 1993). Most of the bird-mammal associations have been observed in Africa, where Moreau (1933), Vernon \& Dean (1988) and Ruggiero (1996), registered at least eight bird families interacting with ungulates. Associations between Corvidae species and ungulates have been recorded in North America (BABER \& MORRIS 1980, Isenhart \& DeSante 1985, Fitzpatrick \& Woolfenden 1996) and Europe (Massei \& Genov 1995, Genov et al. 1998).

In the Neotropics, even though feeding associations are frequently observed, a few have been registered and available informations are reduced. Associations between double-toothed kites Harpagus bidentatus (Latham, 1790) (Accipitridae) and primates are better known than others (GREENLAW 1967, FonTAINE 1980, Boinski \& Scott 1988, Egler 1991, Heymann 1992). Sick (1997) reported that some falcons and toucans forage on preys flushed by coatis Nasua nasua (Linnaeus, 1766) (Procyonidae) and primates in tropical forests, and that the black caracara Daptrius ater Vieillot, 1816 (Falconidae) feeds on ectoparasites of the tapir Tapirus terrestris (Linnaeus, 1758) (Tapiridae) and cervids. The chimango caracara Milvago chimango (Vieillot, 1816) and the yellow-headed caracara M. chimachima (Vieillot, 1816) (Falconidae) are frequently associated with cattle, picking ectoparasites (SICK 1997). In the Amazonian forest, groups of the greater ani Crotophaga major Gmelin, 1788 (Cuculidae) accompany squirrel monkeys Saimiri Voigt, 1831 (Cebidae) to capture insects (Ayres 1985). McCAll (1996) described the interaction between the great egret Casmerodius albus (Linnaeus, 1758) (Ardeidae) and neotropical otter Lontra longicaudis (Olfers, 1818) (Mustelidae), in which the bird forages on fishes that are driven into shallows by the otter's foraging activity. SiLveira et al. (1997) described the association between the aplomado falcon Falco femoralis Temminck, 1822 (Falconidae) and the maned wolf Chrysocyon brachyurus (Illiger, 1815) (Canidae), in which the bird catches the preys that scape from the mammal predator attempts.

Macdonald (1981) registered nine bird species associated with capybaras Hydrochoerus hydrochaeris (Linnaeus, 1766) (Hydrochaeridae), and MARCus (1985) presented new informations on the association between capybaras and wattled jacana Jacana jacana (Linnaeus, 1766) (Jacanidae). Murphey et al. (1985) observed a variety of birds using capybaras to forage (as perches, beaters or to capture ectoparasites), although this author did not mention which bird species were those. Sick (1997) reported kiskadees (Tyrannidae) using capybaras as perches to capture small animals in the aquatic vegetation.

Capybara is the largest living rodent, with total body length ranging from 1.0 to $1.3 \mathrm{~m}$, average shoulder height around $0.5 \mathrm{~m}$ and adult weight reaching $50 \mathrm{~kg}$ or more (EISENBERG \& REDFORD 1999). The capybaras observed in the Lami Biological Reserve contribute with the most mammal biomass and represent the most conspicuous species for the people. It is a grazing herbivore that inhabits in a great variety of habitats (forests, seasonally flooded savannas and mangroves, among others), always in proximity with water (MONEs \& OJASTI 1986). This study presents information on the feeding associations between bird species and capybaras observed in the Lami Biological Reserve, southern Brazil.

\section{MATERIAL AND METHODS}

This study was carried out in the Lami Biological Reserve ( $\left.30^{\circ} 15^{\prime} \mathrm{S}, 51^{\circ} 05^{\prime} \mathrm{W}-179,78 \mathrm{ha}\right)$, located in Porto Alegre, Rio Grande do Sul State, southern Brazil. The climate is characterized by four well-limited seasons, being characterized by high humidity (annual mean 76\%) and dry season absence. The annual mean temperature is $19.4^{\circ} \mathrm{C}$, with maximal temperature in January $\left(37.8^{\circ} \mathrm{C}\right)$ and minimal in July $\left(1.4^{\circ} \mathrm{C}\right)$. The annual mean precipitation is $1,324 \mathrm{~mm}$ (mean between years 1912 and 1997) (Livi 1998). Flooding is observed during the autumn and winter, probably due to a decrease in the evaporation during this period.

The Reserve encompasses a mosaic of wetlands, sandy coastal plain vegetation and water bodies, including the Lami Stream, inside of the study area, and the Guaíba Lake, that surrounds $60 \%$ of the Reserve's perimeter. Five major vegetation types can be found in the study area (Meira \& PORTo 1998): - shrubby and herbaceous swamps (49\% of area), characterized by the occurrence of Cephalantus glabratus (Spreng.) K. Schum. (Rubiaceae), Sebastiania schottiana M. Arg. (Euphorbiaceae), Typha dominguensis Pers. (Typhaceae), Erythrina crista-galli L. (Fabaceae), Zizaniopsis bonariensis (Balansa et Poitr.) Speg. (Poaceae), Panicum elephantipes Nees (Poaceae), Salvinia sp. Seguier (Salviniaceae) e Pontederia Nutt. (Pontederiaceae);

- wet grasslands (15\%), seasonally flooded areas characterized by grasses (Panicum L., Poaceae) and cyperaceans (Cyperus L., Cyperaceae);

- forests (30\%) with a 10m high arboreal stratum, composed by species such as Sebastiania commersoniana (Baillon) Smith et Downs (Euphorbiaceae), Myrcyaria cuspidate O. Berg (Flacourtiaceae), Tabebuia pulcherrima Sandw. (Bignoniaceae), Chrysophyllum marginatum (Hook. et Arn.) Radlk. (Sapotaceae), Ficus organensis Miq. (Moraceae), Vitex 
megapotamica (Spreng.) Mold. (Verbenaceae), Salix humboldtiana Willd. (Salicaceae), Sebastiania schottiana and Inga uruguensis Hook. et Arn. (Mimosaceae);

- sandy grasslands (6\%), characterized by the occurence of the moss Campylopus Brid. (Dicranaceae), the grass Andropogon L. (Poaceae), and the cacti Cereus hildmannianus K. Schum. (Cactaceae) and Opuntia vulgaris Mill. (Cactaceae).

Field work was carried out between January 2000 and May 2002, in the course of a study on the ecology of the capybara, with 35 field expeditions. Ad libitum observations were realized in a set of transects with $7,245 \mathrm{~m}$ of total extension, that traversed the five major vegetation types found in the area. During the observation of birds and capybaras' interactions, the following informations were registered: date and time, vegetation type, bird species, number of individuals (for birds and capybaras), type of prey consumed, foraging strategy of the birds, and behavior of the capybaras in relation to the presence of birds. Data analysis was based on a descriptive interpretation and on the frequency of occurrence of the interactions (number of records of the interaction $x$ in relation to the number of field expeditions, $\mathrm{n}=35$ ).

\section{RESULTS}

The interactions between birds and capybaras were observed in approximately $37 \%$ of the expeditions (13/35) (Tab. I). Five bird species were associated with capybaras: southern caracara Caracara plancus (Miller, 1777) (Falconidae), rufous hornero Furnarius rufus (Gmelin, 1788) (Furnariidae), cattle tyrant Machetornis rixosus (Vieillot, 1819) (Tyrannidae), yellowheaded caracara Milvago chimachima and shiny cowbird Molothrus bonariensis (Gmelin, 1789) (Icteridae). In all cases, birds were benefited by food consumption, feeding on arthropods from the vegetation or from the capybaras' skin, and interacted only with adult and subadult capybaras. Three strategies for prey capture were observed: (1) use of the capybara as a perch, hunting from its back, while the capybara grazes and flushes the arthropods; (2) use of the capybara as a beater, hunting in the ground, while the capybara grazes and flushes the arthropods; (3) foraging in the skin to capture ectoparasites, staying near or landing on the capybara. Capybaras seemed to be indifferent to the presence of Caracara plancus, Fornarius rufus, Machetornis rixosus and Molothrus bonariensis, considering that none reaction was observed.

Caracara plancus consumed only ectoparasites, perching on the capybara to forage (strategy 3). This was observed only one time (3\%), and occurred into the Lami Stream gallery forest while capybaras were resting, at $11 \mathrm{~h}$. In another occasion, one individual of $C$. plancus walked along the stream margin, next to a group of resting capybaras, at $10 \mathrm{~h}$. They did not react to the presence of the bird.

Furnarius rufus consumed ectoparasites from the skin and arthropods from vegetation, using capybaras as beaters (strategy 2). Three interaction occasions were recorded (9\%) in wet grasslands, at $9 \mathrm{~h} 45 \mathrm{~min}$, between 14 and $15 \mathrm{~h}$, and at $18 \mathrm{~h}$.

Machetornis rixosus was the most frequent associated bird species, either regarding frequency of occurrence, interacting in eight occasions (23\%), or number of individuals. It was observed consuming invertebrates from the vegetation in several times of the day between $9 \mathrm{~h} 45 \mathrm{~min}$ and $20 \mathrm{~h}$ (mainly between $16 \mathrm{~h}$ and $20 \mathrm{~h}$ ), frequently with more than one capybara per event. This bird species utilized capybaras as perches and beaters for preying (strategies 1 and 2), by staying on their backs and flying quickly to catch the preys or walking near to the head of grazing capybaras. This association was observed only in wet grasslands.

Molothrus bonariensis was recorded only one time (3\%), in the shrubby swamp at $17 \mathrm{~h} 10 \mathrm{~min}$, consuming arthropods from the vegetation. Three individuals were foraging simultaneously, associated with one grazing capybara, using the strategies 1 and 2 . The two positions for prey capture were alternated: staying on the capybara's back and staying on the branches of the shrub C. glabratus, near to the capybara's head (similarly to hunting in the ground vegetation).

Milvago chimachima was observed only consuming ectoparasites, which were taken by using the strategy 3 . Sometimes, capybaras set in a position that facilitates the cleaning, exposing their flanks and underside. Immediately, the bird started the ectoparasites removal. In other situations, capybaras presented no reaction and the bird picked the upper parts of their bodies. In one occasion, the bird interacted with three capybaras of different groups (one group with five, and other with six individuals), which were foraging separated by $150 \mathrm{~m}$. These capybaras solicited cleaning for M. chimachima by lying down and exposing the abdomen, while practing dust-rolling. All the six occasions of interaction with $M$. chimachima (17\% of the expeditions) occurred in wet grasslands between $16 \mathrm{~h}$ and $20 \mathrm{~h}$, when capybaras were resting or foraging. Milvago chimachima interacted with one, two or three capybaras in each occasion, totalizing 10 observed capybaras. The cleaning solicitation behavior was recorded in $60 \%$ of the observations (6/10).

Milvago chimachima and Caracara plancus were observed as solitary individuals, whereas the other bird species were observed either in groups or solitary individuals (Tab. I). The number of individuals of Furnarius rufus and Machetornis rixosus associated with capybaras in each occasion varied from one to four and from one to six, respectively. In all observations of $F$. rufus, this species formed mixed flocks with M. rixosus.

The interactions were observed most frequently in summer and autumn (Tab. I) and in the middle-late afternoon.

\section{DISCUSSION}

Three species not previously recorded in association with capybaras were registered in this study: Molothrus bonariensis, Caracara plancus and Furnarius rufus. Associations between capybaras and Machetornis rixosus and Milvago chimachima (Vieillot, 1816) (Falconidae) were reported by MACDONALD (1981). Mache- 
Table I. Number of individuals of five bird species associated with capybaras Hydrochoerus hydrochaeris, regarding only field expeditions with record of interactions (13/35) in the Lami Biological Reserve $\left(30^{\circ} 15^{\prime} \mathrm{S}, 5^{\circ} 05^{\prime} \mathrm{W}\right)$, southern Brazil, during 2000 and 2001 . (Sum) Summer, (Aut) autumn, (Win) winter, (Spr) spring.

\begin{tabular}{|c|c|c|c|c|c|c|c|c|c|c|c|c|c|}
\hline \multirow{3}{*}{ Species } & \multicolumn{7}{|c|}{2000} & \multicolumn{6}{|c|}{2001} \\
\hline & Sum & Sum & Aut & Aut & Aut & Win & Spr & Sum & Sum & Sum & Aut & Win & Win \\
\hline & 1 & 2 & 3 & 4 & 5 & 6 & 7 & 8 & 9 & 10 & 11 & 12 & 13 \\
\hline Caracara plancus (Miller, 1777) & 1 & & & & & & & & & & & & \\
\hline Furnarius rufus (Gmelin, 1788) & & & & 4 & 1 & & & 4 & & & & & \\
\hline Machetornis rixosus (Vieillot, 1819) & & 1 & 3 & 6 & 3 & & 4 & 2 & 3 & & 3 & & \\
\hline Milvago chimachima (Vieillot, 1816) & & & & 1 & & 1 & & 1 & 1 & 1 & & 1 & \\
\hline Molothrus bonariensis (Gmelin, 1789) & & & & & & & & & & & & & 3 \\
\hline
\end{tabular}

tornis rixosus is an insectivorous species commonly associated with domestic grazing herbivores such as cattle, using the mammal as a perch or a beater to catch flushed invertebrates (SICK 1997, Belton 2000). Similarly, M. bonariensis is commonly associated with cattle, in small groups, catching disturbed arthropods. However, its feeding habits are more generalist, with seeds and arthropods as the main food items (BeLton 2000). Milvago chimachima typically feeds on ectoparasites from domestic grazing herbivores (SICK 1997). The observations recorded in this study confirm general behavior patterns previously reported for these species, although almost always in associations involving not-wild mammals.

Records about feeding associations involving C. plancus and $F$. rufus were not found in the literature, being this study the first record of these interactions. C. plancus is an omnivorous species, feeding on insects and other invertebrates, carrion, fruits and small vertebrates (SICK 1997). It is known as a potential predator of young capybaras (LORD 1994, JoRGENSON 1986), making this an unexpected association. F. rufus is a typical insectivorous species (AzPIROz 2001), that feeds occasionally on fruits and seeds (SICK 1997, BeLTON 2000).

Although the number of observations in this study was very low to permit statistical approaches, a tendency of a greater number of interaction events during the summer and autumn was found. This fact that could not be explained by our observations because there is not a coincidence with the high numbers of animals registered and the interaction events. Birds showed a probable preference to associate when capybaras were grazing (principally in middle-late afternoon), considering species that feed on flushed arthropods, what is explained by the necessity of movement to disturbed preys. Bird species that feed on ectoparasites can forage when capybaras are resting or foraging. Thus, the activity of the birds seems to be related to the activity type developed by capybaras in each period of the day. This relation was observed by BoINSKI \& SCOTT (1988) and KäLLANDER (1993) in bird-primate and bird-cattle associations, respectively.

The observed associations can be classified as occasional or opportunistic (VERNON \& DEAN 1988) and, more specifically, they can be classified as protocooperative (regarding C. plancus and M. chimachima) and commensalistic interactions (regarding M. bonariensis and M. rixosus). The relationship involving F. rufus presents characteristics of both interaction types and this species can be considered as a protocooperative or a commensal in relation to capybaras.

Macdonald (1981) also observed the "cleaning solicitation" behavior during interaction between capybaras and $M$. chimachima. This author reported one capybara exhibiting its nostril to this bird to obtain tick removal. Azcarate (1980) and LORD (1991) observed the same behavior recorded in our study, in which the capybara exposes its flanks and underside. This behavior were observed in other bird-mammal associations, like those between Tapirus terrestris and Daptrius ater (SICK 1997), and between the feral hog Sus scrofa Linnaeus, 1758 (Suidae) and Corvidae (Kilham 1982, Massei \& Genov 1995).

In the Venezuelan Llanos, MACDONALD (1981) observed relationships between capybaras and six species pertaining to Ardeidae, Jacanidae and Threskiornithidae families. Despite the great abundance of aquatic bird species in the swamps found in the Lami Biological Reserve, interactions between capybaras and these species were not observed, possibly due to the low number of observations of capybaras in swamps (only $7 \%$ of the total observations, including all vegetation types).

\section{ACKNOWLEDGEMENTS}

The authors are grateful to the Administration of the Lami Biological Reserve; to the CAPES and FAPERGS for the scholarships for the first and second authors respectively and to the Drs. Jorge Rabinovich, Emerson Vieira and Thales Renato O. de Freitas for the critical and comments of the manuscript.

\section{REFERENCES}

Ayres, J.M. 1985. On a new species of squirrel monkey, genus Saimiri, from Brazilian Amazonia (Primates, Cebidae). Papéis Avulsos de Zoologia, São Paulo, 36 (14): 147-164.

Azcarate, T. 1980. Sociobiologia y manejo del capibara (Hydrochoerus hydrochaeris). Doñana Acta Vertebrata, Sevilla, 76: 1-228.

Revista Brasileira de Zoologia 22 (3): 712-716, setembro 2005 
Azpiroz, A.B. 2001. Aves del Uruguay. Montevideo, Aves Uruguay-GUPECA, 104p.

BABER, D.W. \& J.G. MorRIS. 1980. Florida scrub jays foraging from feral hogs. Auk, Lawrence, 97: 202-202.

Belton, W. 2000. Aves do Rio Grande do Sul - Distribuição e Biologia. São Leopoldo, Unisinos, 584p.

BoInski, S. \& P.E. ScotT. 1988. Association of birds with monkeys in Costa Rica. Biotropica, Washington, 20: 136-143.

Egler, S.G. 1991. Double-toothed Kites following tamarins. Wilson Bulletin, Lawrence, 103: 510-512.

EISENBERG, J.F. \& K.H. REDFORD. 1999. Mammals of the Neotropics - The Central Neotropics. Chicago, The University of Chicago Press, 609p.

Fitzpatrick, J.W. \& G.E. Woolfenden. 1996. Florida Scrub-jay forages on back of white-tailed deer. Condor, Los Angeles, 98: 422-423.

FonTAINE, R. 1980. Observations of the foraging association of Double-toothed Kites and white-faced capuchin monkeys. Auk, Lawrence, 97: 94-98.

Genov, P.V.; P. Gigantesco \& G. Massei. 1998. Interactions between Black-billed Magpie and fallow deer. Condor, Los Angeles, 100: 177-179.

GreENLAW, J.S. 1967. Foraging behavior of the Double-toothed Kite in association with white-faced monkeys. Auk, Lawrence, 4: 596-597.

Heatwole, H. 1965. Some aspects of the association of Cattle Egrets with cattle. Animal Behaviour, London, 20: 421-424.

Heymann, E.W. 1992. Associations of tamarins (Saguinas mystax and Saguinas fuscicollis) and Double-toothed Kites (Harpargus bidentatus) in Peruvian Amazonica. Folia Primatologica, Basel, 59: 51-55.

Isenhart, F.R. \& D.F. DeSANTE. 1985. Observations of Scrub Jays cleaning ectoparasites from black-tailed deer. Condor, Los Angeles, 87: 145-147.

Jorgenson, J.P. 1986. Notes on the ecology and behavior of capybaras in northeastern Colombia. Vida Silvestre Neotropical, Washington, 1 (1): 31-40.

Källander, H. 1993. Commensal feeding associations between yellow wagtails Motacilla flava and cattle. Ibis, London, 135: 97-100.

Kilham, L. 1982. Cleaning/feeding symbioses of Common Crows with cattle and feral hogs. Journal of Field Ornithology, New Ipswich, 53: 275-276.

Livi, F.P. 1998. Elementos do clima: o contraste de tempos frios e quentes, p. 73-78. In: R. Menegat (Ed.). Atlas Ambiental de Porto Alegre. Porto Alegre, Editora UFRGS, 238p.

LoRD, R.D. 1991. Twenty-four-hour activity and coprophagy by capybaras (Hydrochaeris hydrochaeris). Studies on Neotropical Fauna and Environment, Lisse, 26 (2): 113-120.

LORD, R.D. 1994. A descriptive account of capybara behaviour.
Studies on Neotropical Fauna and Environment, Lisse, 29 (1): 11-22.

Marcus, M.J. 1985. Feeding associations between capybaras and jacanas: a case of interspecific grooming and possibly mutualism. Ibis, London, 127: 240-243.

MaCDONALD, D.W. 1981. Feeding associations between capybaras Hydrochoerus hydrochaeris and some bird species. Ibis, London, 123: 364-366.

Massei, G. \& P.V. Genov. 1995. Observations of Black-billed Magpie (Pica pica) and Carrion Crow (Corvus corone cornix) grooming wild boar (Sus scrofa). Journal of Zoology, London, 236: 338-341.

MCCALL, R. 1996. A novel foraging association between southern river otters Lutra longicaudis and great egrets Casmerodius albus. Bulletin of the British Ornitologists' Club, London, 116 (3): 199-200.

Meira, J.R. \& M.L. Porto. 1998. Reserva Biológica do Lami: a vida na beira do lago, p. 89-92. In: R. Menegat (Ed.). Atlas Ambiental de Porto Alegre. Porto Alegre, Editora UFRGS, 238p.

Mones, A. \& J. OJASTI. 1986. Hydrochoerus hydrochaeris. Mammalian Species, Lawrence, 264: 1-7.

Moreau, R.E. 1933. The food of the Red-billed Oxpecker (Buphagus erythrorhynchus). Bulletin of Entomological Research, Farnham Royal, 24: 325-335.

Murphey, R.M.; J.S. Mariano \& F.A.M. Duarte. 1985. Behavioral observations in a capybara colony (Hydrochoerus hydrochaeris). Applied Animal Behaviour Science, Amsterdam, 14: 89-98.

Odum, E.P. 1988. Ecologia. Rio de Janeiro, Editora Guanabara Koogan, II+434p.

RAND, A.L. 1953. Factors affecting feeding rates of anis. Auk, Lawrence, 70: 26-30.

Rodrigues, F.H \& E.L.A. Monteiro-Filho. 1996. Comensalistic relation between pampas deer, Ozotocerus bezoarticus (Mammalia: Cervidae) and rheas, Rhea americana (Aves: Rheidae). Brenesia, San José, 45-46: 187-188.

RugGIERo, R.G. 1996. Interspecific feeding associations: mutualism and semi-parasitism between hippopotami Hippopotamus amphibius and African jacanas Actophilornis africanus. Ibis, London, 138: 346-348.

SICK, H. 1997. Ornitologia Brasileira. Rio de Janeiro, Nova Fronteira, 912p.

Silveira, L.; A.T.A. Jácomo; F.H.G. Rodrigues \& P.G. Crawshaw Jr. 1997. Hunting association between the Aplomado Falcon (Falco femoralis) and the maned wolf (Chrysocyon brachyurus) in Emas National Park, Central Brazil. Condor, Los Angeles, 99: 201-202.

SMITH, S.M. 1971. The relationship of grazing cattle to foraging rates in anis. Auk, Lawrence, 88: 876-880.

Vernon, C.J. \& W.R.J. Dean. 1988. Further African bird-mammal feeding associations. Ostrich, Cape Town, 59 (1): 38-39.

Received in 10.I.2005; accepted in 17.VIII.2005. 